\title{
The Antecedents of Taxpayers Compliance Behavior and the Effectiveness of Thai Local Government Levied Tax
}

\author{
NichapatBoonyarat \\ Faculty of Management Science \\ SongkhlaRajabhat University \\ Thailand \\ Syed Sofian \\ College of Business \\ University Utara Malaysia \\ Malaysia \\ WanidaWadeecharoen \\ Thonburi University \\ Bangkok \\ Thailand
}

\begin{abstract}
Purpose: This study is the primary research identifying the components of tax fairness perception, tax knowledge and understanding, attitude towards taxation, service quality and their effects on taxpayers' satisfaction.

Methodology/Sampling: A systematic random sampling technique was used for selecting taxpayers via SAO's name list, by counting the person with every the end of numbers are the first and the sixth in the list be justified.Structural Equation Modeling (SEM) was used to test the cause relationship among tax fairness perception, tax knowledge and understanding, attitude towards taxation and service quality with taxpayer's satisfaction and their compliance behavior empirically.

Findings: To solve the shortages of government revenue, due to ineffective local government administration in developing countries, there are four sources antecedent factors were identified in this study. They are tax fairness perception, tax knowledge, and understanding, attitude towards taxation and service quality. These factors were assuming efficiency in tax collection which effecting to taxpayer's satisfaction and their compliance behavior.

Practical Implications: The research provides findings from first study on land Thai local tax, identifies the strategic factors for enhancing of local government revenue, and improve living standard of Thai local people.
\end{abstract}

Keywords: Tax, Compliance Behavior, Local Government, Thailand.

JEL Classification: H2, H71.

\footnotetext{
*The material presented by the authors does not necessarily portray the viewpoint of the editors and the management of the Institute of Business \& Technology (IBT).

* NichapatBoonyarat: tubskru@ hotmail.com

* Syed Sofian: sofian@uum.edu.my

* WanidaWadeecharoen: wadeecharoen@gmail.com

CJMSS is published by the Institute of Business and Technology (IBT). Main Ibrahim Hydri Road, Korangi Creek, Karachi-75190, Pakistan.
} 


\section{INTRODUCTION}

Thailand local tax is a major source of Tambon or Sub-district Administrative Organization (SAO) revenue for local empowerment. Tax kinds and rates had been fixed by the central government for almost one hundred year time, after changing the form of government from an absolute monarchy to a democratic since year 1932 (Hongvivatana, 1972).

According to Vachirawanwong, (1988) found that 'there are three causes caused to insufficient revenue structure of municipality'; they were (1) laws and regulations concerning revenue structure were obstacles to revenue collection capability; (2) Low efficiency of municipality in revenue management and (3) the municipality has no initiative to seek more revenue from any business undertaking. Despite, the study of Sonnakul, (1990) found the relationship between government tax revenue policy and local taxation behavior. This is because of when the local government purposes a new policy of raising tax, then for the next local election, they will face with the high failure of being elected. As of this point, Thai local government has gave less importance to revenue collection while relied on expense control (Ruangpoeng, 2002). To prevent of populism loss, local government will not interests to seeking more revenue.

Since, Thai local government ignores to seek more tax revenues while they were also leakages in revenue collection with low efficiency. This cause most of local administration organization (SAO) has faced with shortage revenue for doing activities works and meets the expectation of people in SAO (Conrad Adenau, 2005).

Hence, seeking the way to enhance of local tax revenue enable to respondent the needs and expectation of Thai local people. Service quality of government staff was identified as the important factor determining efficiency in tax collection which leads to taxpayer's satisfaction with the service provided by municipality (Nantatikul, 2002). Similarly to Chanpaisansin, Meemak and Chayachawalit, (2007) show that service quality is the second success factors next from organization development. Moreover, Siriwat, (2009) summarized that taxpayer's perception; knowledge and their attitude have participation relationship toward sub-district administrative organization (SAO). Keopradit, (2009) suggest that publicity of knowledge and information regarding to regulations and taxation procedures should be done throughout the municipality area. As suggested by Wiriyathampaisan, (2002) state that "using Geographic Information System (GIS) application for classifying tax data base and land area before assessment was more efficient than manual method'. This is some example for 'good service system' which will mediate taxpayers willing to pay more tax. Choice of payment via bank counter or internet banking becomes important alternative. Tax roadmaps and property registration systems will facilitate imposition from both personal tax and land tax. These are the determinant factors which will help to increase of local tax revenue to the target or more up.

Despite, due to the operational of SAO, there were some difficulties and obstacles in the two areas. These are such as (1) personal service quality and (2) limitation of administration resources. Based on the study of Cheutong, (2007) stated that appropriate tax period, tax discount, clear taxation process, lack of space for waiting area, no attentive welcoming gestures and the basic facilities i.e. drinking water, newspaper. These components must be taken for local government consideration. In addition, local businessmen are not revealing their actual finance statement and not willing to cooperate with SAO. In other hand, they try to hidden beneficial information for the SAO due to protecting their business advantage (Puang-ngam and Chotchuang, 2001; Kruerdhep, 2012). These are all 
reasons why Thai local government could not collect the actual among of tax while their budgets were relies on central government (Suthirat, 2002).

\section{RESEARCH BACKGROUND AND PROBLEM STATEMENT IN THAILAND}

The major Thailand local empowerment financial support came from Thailand local tax. Tax revenue is the most important for SAO administration, created job and project implementation through an annual budget. Tax evasion will affect shortage budget of local development. Thus, when the government has received insufficient revenue then will cause to weakness of nation fiscal status and finally will increase public debt in Thailand (Trakarnsirinont, 2007). Therefore, several Thai government try to find ways to increase more tax and enhance nation revenue. This revenue will be spending for national development. Despite, most of the taxpayers are not willing to spending much more on tax which they may have reaction against the government policy (Prajuabmon, 2001; Cheutong, 2007).

In 1990, government has decentralization act by transferred the power from central government to SAO, including the authority, responsibility and manpower. Based on this act, government expected to receive revenue up to 35 percent of total income within year 2006. Despite, in fact SAO has not received sufficient revenue to expend for the local demand (Pornchokchai, 2009; Kruerdhep, 2012). This is because the performance of local government tax system was very poor while their collecting tax income was less than 10 percent of its overall income (refer to Table 1:Revenue of Local Government Organization in the Fiscal Year 2009). As of this point, it's become burden for central government to support SAO development more than 90 percent of their total income. Therefore, SAO should act as the self-governed by created strategic planning to conduct more tax revenue from local taxpayers.

Table 1

Revenue of Local Government Organization in the Fiscal Year 2008

\begin{tabular}{|c|c|c|c|c|}
\hline & Revenue Types & SAO & Total & Percentage \\
\hline \multirow[t]{14}{*}{$\mathbf{1}$} & Local Levied Taxes & $7,064.69$ & $35,223.60$ & 9.35 \\
\hline & 1.1 Revenue from Local Levied Tax & $3,703.30$ & $22,776.99$ & 6.05 \\
\hline & Building and Land Tax & $2,401.68$ & $17,164.77$ & 4.56 \\
\hline & Local Development Tax & 839.69 & $1,274.87$ & 0.34 \\
\hline & Signboard Tax & 283.19 & $1,640.60$ & 0.44 \\
\hline & Slaughter Duty & 20.01 & 89.68 & 0.02 \\
\hline & 1.1.5 Bird Nest Duty & 165.13 & 202.19 & 0.05 \\
\hline & 1.1.6 Tax from Tobacco, Oil, and Hotel & & $2,404.88$ & 0.64 \\
\hline & 1.2 Non-tax Revenue & $2,716.25$ & $9,434.81$ & 2.50 \\
\hline & User Charge, License Fee, Fine & $1,031.80$ & $3,819.28$ & 1.01 \\
\hline & 1.2.2 Property Revenue & 165.64 & $1,972.50$ & 0.52 \\
\hline & Utility Income & 424.96 & 811.06 & 0.22 \\
\hline & 1.2.4 Other Revenue & $1,093.95$ & $2,831.97$ & 0.75 \\
\hline & $\begin{array}{l}1.3 \text { Revenue from increasing efficiency of Local } \\
\text { Collection }\end{array}$ & 640.74 & $3,011.80$ & 0.80 \\
\hline \multirow[t]{3}{*}{2} & Surcharge Tax & $50,173.56$ & $128,676.40$ & 34.1 \\
\hline & 2.1 Value Added Tax & $15,531.93$ & $84,771.54$ & 22.50 \\
\hline & 2.2 Specific Business Tax & 522.39 & $4,000.00$ & 1.06 \\
\hline
\end{tabular}




\begin{tabular}{|c|c|c|c|c|}
\hline & 2.3 Beverage Tax & $6,553.59$ & $9,250.00$ & 2.46 \\
\hline & 2.4 Excise Tax & $4,631.35$ & $20,681.61$ & 5.49 \\
\hline & 2.5 Vehicle Tax & & $22,510.74$ & 5.78 \\
\hline & 2.6 Immovable property Register Fee & $11,226.06$ & $26,952.28$ & 7.15 \\
\hline & 2.7 Gambling Tax & & 145.00 & 0.04 \\
\hline & 2.8 Mineral Fee & 613.84 & $1,064.00$ & 0.28 \\
\hline & 2.9 Petroleum & 912.69 & $1,522.00$ & 0.40 \\
\hline & 2.10 Other & 135.31 & 165.00 & 0.04 \\
\hline 3 & Shared Tax & $31,667.07$ & 65,000 & 17.25 \\
\hline 4 & Total Local Revenue before Grant $(1+2+3)$ & $88,905.32$ & 228,900 & 60.76 \\
\hline 5 & Grant & & 147,840 & 39.24 \\
\hline 6 & Total Local Revenue $(4+5)$ & $88,905.32$ & 376,740 & 100 \\
\hline 7 & Government Revenue & $1,495,000$ & $1,495,000$ & \\
\hline 8 & $\begin{array}{l}\text { Proportion of Local Revenue Total Revenue to } \\
\text { Government Revenue }\end{array}$ & 383 & 25.20 & \\
\hline
\end{tabular}

Source: Office of the Decentralization to Local Administrative Organization Committee (2009).

In sum, shortages of government revenue and social infrastructure are usually occurring in developing countries such as Thailand and some other countries in Asia. This is because in developing countries needs fast developing in infrastructure, technology, education and even changing people's quality of life. Thus, to enhance Thai people standard of life, government should providing budget on medical treatment and premiums for the elderly sufficiently. As of this point, Thai central and local government must be strengthened to be self-reliance by seeking revenue to meet the expenses and demand. Consequence, land local tax is the important source of local government revenue for development community. Therefore, this research will be focus on land local tax and identify the strategic factors for enhancing of local government revenue and improve living standard of Thai local people.

\section{RESEARCH QUESTIONS}

1. What are the components of Thailand local tax fairness perception?

2. What are the components of Thailand local tax knowledge and understanding?

3. What are the components of the attitude towards Thailand local taxation?

4. What are the components of Thailand local tax service quality?

5. What are the components of taxpayers' satisfaction influencing Thailand local tax compliance behavior?

6. How is the relationship between; tax fairness perception, tax knowledge and understanding, attitude towards taxation and service quality with Thailand local taxpayers' satisfaction and tax compliance behavior?

7. How are the influential paths in the structural equation modeling among tax fairness perception, tax knowledge and understanding, attitude towards taxation and service quality, taxpayers' satisfaction and Thai land local tax compliance behavior?

\section{RESEARCH OBJECTIVE}

1. To identify the components of tax fairness perception affecting Thai land local taxpayers' satisfaction.

2. To identify the components of tax knowledge and understanding affecting Thai land local taxpayers' satisfaction. 
3. To identify the components of attitude towards taxation affecting Thai land local taxpayers' satisfaction.

4. To identify the components of service quality affecting Thai land local taxpayers' satisfaction.

5. To identify the components of taxpayers' satisfaction influencing Thai land local tax compliance behavior.

6. To study the relationship and influential paths of the antecedents or causal variables: tax fairness perception, tax knowledge and understanding, attitude towards taxation, service quality; the mediating variable of taxpayers' satisfaction; and effect variable of Thai land local tax compliance behavior.

7. To study the influential paths in the structural equation modeling among tax fairness perception, tax knowledge and understanding, attitude towards taxation and service quality, taxpayers' satisfaction and Thailand local tax compliance behavior.

\section{THE LIMITATION OF THE STUDY}

The limitation of this study classified into two scopes such as;

1. Content Limitation: This study focus on the antecedents of taxpayers' satisfaction and their compliance behavior in sub-district administration organization in Thailand. These antecedents were included tax fairness perception, tax knowledge and understanding, attitude towards taxation and service quality. These are the antecedents explain by compliance behavior theory. This theory describe that generally people do not like to pay the tax (Prajuabmoa, 2001; Cheutong, 2007). To make people accepted the regulation 'why people pay tax'; the government must change their attitude towards taxation. Therefore, the government should design the tax system in such a way that tax collectors and taxpayers have chance to cooperate and understand what they will get turn from their money (Kewpradit, 2009). Thus, these are all the content limitation and overall concept of the study intentionally focused on taxpayer behavior.

2. Time consumption Limitation: The duration for gathering field data will be only one month. Therefore, completing of taxpayer's behavior survey data from a single state could be a best alternative due to time consumption (Sweangdee, 2011). Collecting data from different state and wide area may lead to difficulty to receive a consistency data. To defense this problem, this study will completing of taxpayer's behavioral survey data from single locality can be as well representative to the other state (Sweangdee, 2011).

\section{EXPECTATION OF THE STUDY}

This study will give a new body of knowledge on tax compliance behavior of Thai local people development in particular areas such as below;

1. The results of the study will give some advices for development of local tax office service quality.

2. The finding of this study will give the new direction for improving local tax collection administration. 
3. This study will be awareness of factors affecting taxpayers' satisfaction and their tax compliance to local government. Emphasizing on these particular research factors will motivating local people willingness to pay tax and increasing tax revenue.

4. The overall research will enhance the efficiency of local tax collecting agencies.

\section{LITERATURE REVIEW}

Underlying local taxpayer compliance behavior is reviewed in order to support each variable, the associations among them, and the structure of the research model. These include such conceptual theory, related research, and the antecedents of the land local taxpayer compliance behavior, as the detail of each topic is elaborate. Cannon (1976) stated that Adam Smith said taxes levied from the rental land be the most efficient ones to local. A land rent is the value agriculturist paid for the right of using land to land owner. Thus, owners are not troubled from government increasing the land local tax rate, but might be trouble of hirer. Local Levied Revenue will be expenses to improve social environment in local as ways, ditch, water-supply, electricity etc. by local levied tax related to the land will also increase the wealthy of land to owner mutual satisfaction.

According to literature survey and result of past research study, this research sorted the choice six factors to elaborated in to theoretical framework of the study (refer to Figure 1). They are four antecedents are as tax fairness perception, tax knowledge and understanding, attitude towards taxation, and tax service quality. These factors will determine taxpayers' satisfaction which will eventually toward to taxpayer compliance behavior. Prior studies just mentioned factors are as below.

\section{Compliance Behavior}

Tax is the burden that people do not like to pay (Prajuabmoa, 2001, Cheutong, 2007). The government should design the tax system in such a way that tax collectors and taxpayers have no chance to cooperate for tax evaders' gain nothing from tax evasion (Kewpradit, 2009).

According to 'Behaviorism School', man have brain for thinking and remembering brought by 'Exogenous Factors' which will influence human behavior both in the present and in the future.

(Phalalerd, 2005; Julphanthong, 2010).

Honest paying tax involves filling out tax assessment forms truthfully, continuous paying annual tax, and persuading other people to do so accordingly to tax calendar. People's complete tax payment will strengthen their Sense of Belonging to SAO. Lack of participation among people was due to being unrealized that many facilities built by SAO with gets provided by central government, actually, are revenues from their own tax payment (Punagngam, 2009; Krueathep, 2012). People participant behaviors include following the SAO's regulations, supporting SAO's development schemes, joining SAO's election as a candidate, examining and watching SAO's performances, joining SAO's team for public relation in seeking participation of people and paying tax honestly (Puang-ngam\&Chotchuang, 2001; Yolau\&Kasemnet, 2008).

This, to enhance the effectiveness of Thai local government levied tax; examine the antecedent factors of taxpayer's compliance behavior is important to clarify empirically. These antecedents are such as below. 
1. Tax fairness perception: Perception of tax fairness has certainly been recognized widely as one of the important variables that influence tax compliance behavior (Gilligan \& Richardson, 2005). This is because perception is a process for accumulating information through Sensory Organs. The derived information will be sent to the brain for processing by interpretation, learning, realizing and remembering while the brain may execute for some behaviors. This effort will be very much beneficial to the government from the tax compliance satisfaction of the people, resulting persuade their fellows to participate in paying tax sincerity (McBarnett, 2006; Thoomkosit, 2009; Kruerdhep, 2012). Tax consciousness in the long-run, from a government should try hard to build and also pay attention to the process of people compliance behavior, which is very important for public performance. In additional, budget will be equitably allocated for local development. These conditions will take tax fairness perception and eventually enhance taxpayer compliance behaviors.

2. Tax knowledge and understanding: According to Tayib, (1998) found that local taxpayers' compliance behavior built from their tax knowledge well laid tax system that was easy to study and comprehend. Puang-ngam (2009) revealed that people had not enough knowledge on SAO system. Due to this lack of understanding on their right and duty as a good local citizen, the role of SAO, had inefficient local government administration and its failure. It also caused negative public acceptance towards SAO and also low tax compliance satisfaction (Thoomkosit, 2009; Kruedhep, 2012). Therefore, it's necessary for the government to educate the public that revenue levied by SAO is for community development. Hence, when the people have sufficient knowledge about land local tax, many more tax may receive from public.

3. Attitude towards Taxation: Beside of attitude is expressed in three forms: positive, negative, and neutral. Attitude could be changed through changing their value and belief. Positive attitude may be strengthened into preference, strong liking or positive response towards any particular circumstance, which is the expression of satisfaction and behavior (Palil, 2010; Thongboonma, 2010). Attitude towards taxation, then, is important to tax compliance (Jackson \&Milliron, 1986 as cited in Tayib,1998). Attitude is an important factor trying with satisfaction that will lead to Thai taxpayers' compliance behavior. Thus, local government should motivate the positive attitude towards SAO. This will be helpful in dealing with local fiscal and in seeking people acceptance to any government undertaking.

4. Service Quality: Service quality could be measured by using Client Satisfaction Index: CSI, after services having given to clients. Their worth, while feelings will lead them to return in servicing again and again (Ramangkoon, 2009). Seemanee (2003) had pointed out that good service principles are: 1) Continuous Service with public interest as a major aim without being concerned the termination of the services. 2) Equitable Service to everybody or fair service provision according to law. 3) Convenient Service, easy to do, no difficulty to both service givers and receivers, etc. Developing high service spirit personnel is the very important responsibility of an organization. Differentiation in services provision among competing organizations must be followed in such a way that better quality of service must be provided. This accomplishment will help increase clients to the organization through their mouth to mouth publicity. This research determines that service quality, involves the matters of empathy, reliability, and tangibles, is a factor contributing to taxpayers' satisfaction relationship with taxpayer compliance behavior. 


\section{Taxpayer's Satisfaction}

Satisfaction means feeling like, gratified, pleased, happy. It reflects one's attitude, or emotional move towards something, together with its environment. A person's satisfaction will result in his/her different behaviors (Thongboonma, 2010; Palil, 2010).

According to President Abraham Lincoln state that "if the people were satisfied, there will be no failure, but if there were no people's satisfaction, there will be no success" (Lapiratanakul, 2006)

Public satisfaction is from public goods and services provided by local government. They are temples, mosques, roads, canals, ditches, bridges, bus depots, piers, incinerators, land and water traffic routes, city cleaning education, fire distinguish equipment etc. Local government maintains these goods and services in order to meet people needs and satisfaction. Through these public goods and services, they show morale and attitudes (Yarnmanowisit, 2008). If taxpayers realize that tax revenue paid, was expended for their own and local benefits, they will be very happy to pay. Thus, the government should always bear in mind on the satisfaction people have towards public goods, and try to carry out with equity, adequacy, continuity and progress, by which people's attitudes will be the result (Wongkiatkhajorn, 2009).

This study of the behaviors of tax compliance behaviors of Thai land local taxpayers aims at examining satisfaction towards tax system, factors contributing to tax compliance satisfaction, including jobs to be done to achieve highest satisfaction. In this study, tax compliance satisfaction is treated as a new variable leading to deep structured problem solving satisfaction leading to participation will be derived through analysis of four antecedents: they are; tax fairness perception, tax knowledge and understanding, attitude towards taxation, and service quality.

\section{The Definition of Term}

Local Thai $=$ Thai rural area or Thai underdeveloped regions which far from the cities.

Local Development Tax $=$ Tax collected from the land owner in the suburb and rural area.

$\mathrm{SAO}=$ Sub-district Administrative Organization

\section{RESEARCH MODEL}

The research mode of this study consists with four independents, one intermediate and dependent variables. There are four independent exogenous latent variables: tax fairness perception, tax knowledge and understanding, attitude towards taxation and service quality. These variables were active behind the manifest variables called 'caused variables antecedents'. 
Taxpayer's satisfaction is performing as the intermediate variables in research model. It's play the role of linkages relationship between antecedent variables and influenced to the dependent variable. Tax compliance behavior is the only one dependent variable in this research model (see Figure 1).

\section{Figure1}

Research Model

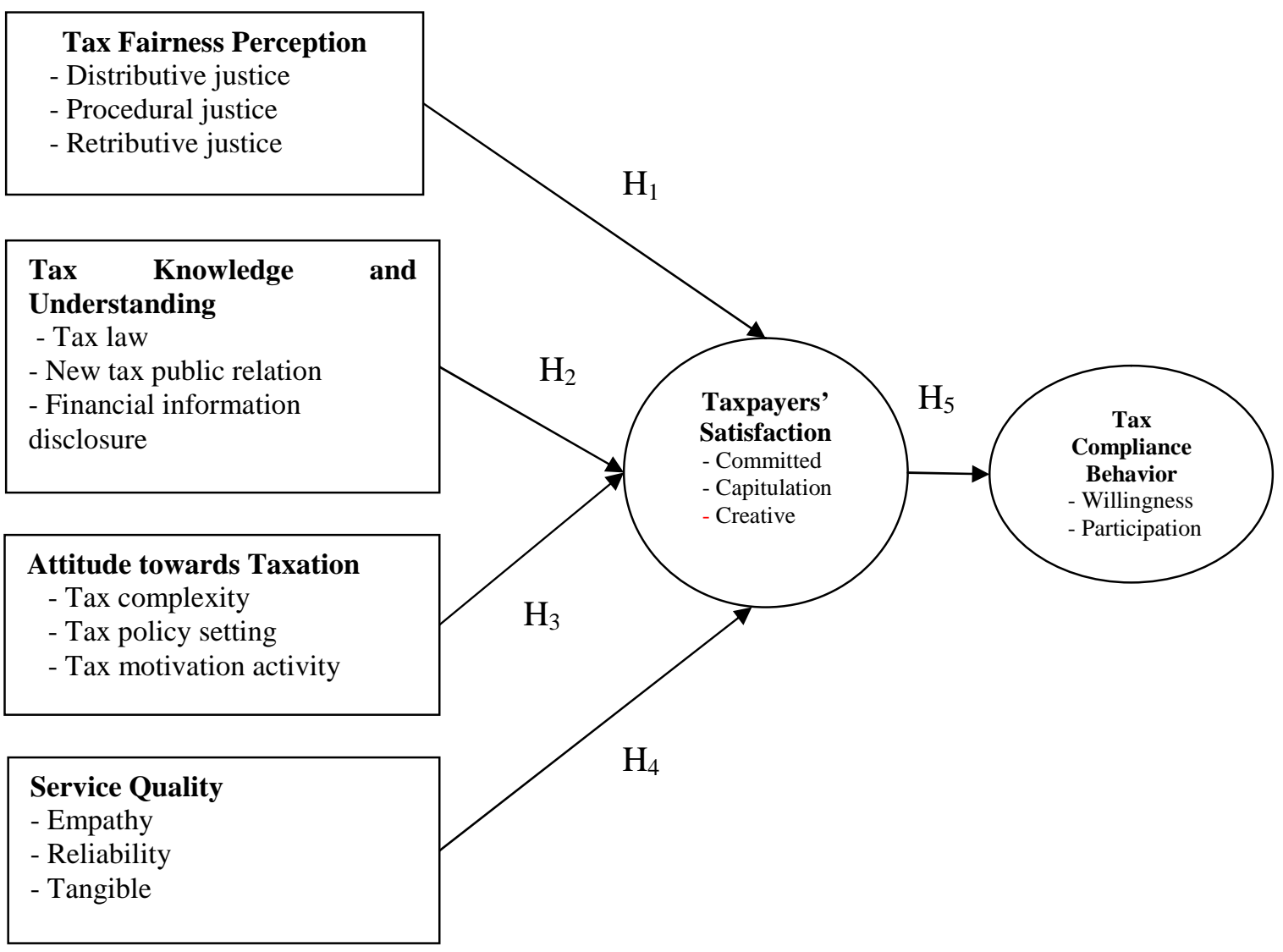

Source: adapted from Tayib (1998)

\section{RESEARCH METHODOLOGY}

There are three categories of research variables will examine in this study. They were antecedents, intermediate variable and dependent variables (refer to figure 1). Thus, to verified the antecedents of taxpayers' satisfaction and tax compliance behavior. This research will be carried out systematically methodology which included the following steps are such as research design, research hypothesis, data collection process, data analysis and result verification. 


\subsection{Research Design}

This research served to address the problem issues of high rate of public debt while government tax collection is less than 10 percent of overall revenue. The aim of the study is finding the true for expounding the rational generated of this phenomenon. Descriptive survey was selected to capture the general information of the respondent.

A causal research was also included in this study. Structural Equation Modeling (SEM) will use to analyzing and explaining the causal variables relationship and their cause effect relationship on tax compliance behavior.

To achieve the beneficial of academic and practitioner, this study has adapted both qualitative and quantitative technique to examine the overall picture of taxpayers' satisfaction and their compliance behavior (Wiratchai, 1995; Prasith-rathsint, 2009). With all these steps of research design enable the researcher getting understood into the actual problem issues and come out with research the answer effectively.

\subsection{Population and Sampling Size}

A sampling for descriptive survey must be effective use to conclude the research questions and objectives. Social science research basically requires a large number of sampling size as a good representative of total population.

According to Kiranan (1998) as cited in Thuwachot (2001) stated that 'Use the largest sample according to your capability'. This is because of a large number of samples will get the more truthful results and the better reliable conclusion. In case of taxpayer in Thailand as a whole country, a sample of less than a percent of population may reliable which refer that the sampling technique suggested by Thuwachot, (2001) is appropriate (STOU, 2009). Thus this research sampling will used of eight hundred sampling to derive actual data and testing hypotheses (Sookasame\&Prasith-rathsint, 2007).

Antecedent sampling technique will get a good sample for quantitative technique data (Deming, 1950 cited in Yamane, 1967). Multi-stage cluster sampling will applied at the national, regional province and SAO levels (Promjui, 2001; STOU, 2009). Moreover, the systematic random sampling technique will used for selecting taxpayers via SAO's name list, by counting the person with every the end of numbers are the first and the sixth in the list (Hair et al., 2010).

According to SAO's list of taxpayers, there were diversities of gender, age, education, occupation, income and property ownership duration, as well as their participation in local affairs. However, these diversified characters are under the same constitutional law. Therefore, completing of taxpayer's behavioral survey data from single locality can be as well representative to the other state (Sweangdee, 2011). This is because obtaining a data from different state and wide area may lead to difficulty to receive a consistency data. Close supervision in every research steps to prevent of false data and getting a precision of research value (Wiersma, 1986; Pongwichai, 2009). Thus, a single province was selected to represent taxpayer's behavior in the whole country. 
In addition, documentary technique was analysis from literature review, tax statistic data from local administration office, statistic bureau, electronic media and complement with qualitative technique via personal in-depth interview. Field research will collected from department of local administration office at Trang province. The interviewer of this research classified into three groups; they were the heads government agency, local government office and taxpayers.

\section{RESEARCH HYPOTHESIS}

According to research model of the study, there are five hypotheses were generated such as following;

The distributive justice in term of provision of public goods and services will be brought into comparison. Procedural justice as well as retributive justice for those who evade tax payment will lead to tax compliance satisfaction of taxpayers. Thus, the first hypothesis (H1) is:

H1: Tax fairness perception has a relationship with taxpayer's satisfaction

Most of taxpayers pay tax because of law requirement but some are tax evaders of some kinds. It is necessary for government agencies to lead taxpayers' satisfaction. As a theoretical conviction, when people gain more knowledge an better understanding tax, especially, in tax law, new tax under public relation efforts and also disclosure of government financial information, will induce more consciousness about tax fairness. Tax knowledge and understanding also affect people attitudes and will lead to tax compliance satisfaction. Thus, the second hypothesis $(\mathrm{H} 2)$ is:

H2: Tax knowledge and understanding has a relationship with taxpayers' satisfaction

These will help forming good attitude towards tax complexity, tax policy setting and tax motivation activity will lead to tax compliance satisfaction. Thus, the third hypothesis (H3) is:

H3: Attitude toward taxation has a relationship with taxpayers' satisfaction

Efficiency of tax collection may be measured by amount of revenue collected. Service quality can enhance taxpayers' satisfaction that will lead them to return again. Service quality includes willingness to provide tax services, to serve with politeness and heartedly intention for any problems arising, with reliability and equitable practices to every taxpayer, staffing with good personality tax personnel ready for clear answers to any questions. Sufficient availability of tangible, with a neat clean, modern, convenient office that support delivering service immediately will lead to taxpayers' satisfaction. Thus, the fourth hypothesis (H4) is:

H4: Service Quality has a relationship with taxpayers' satisfaction

Taxpayers' satisfaction can be measured by frequency of tax complaints, levels of acceptance to tax burdens. Tax incentives through tax reduction for taxpayers who pay tax in time are not now available in Thailand, a measure that will contradict to tax revenue enhancement effort of the government. Level of desire to pay tax also demonstrates tax compliance that will show tax compliance satisfaction. Taxpayers' satisfaction will result in 
tax compliance behavior in paying tax honestly in time and continuously. It also results in persuading village folks to join in paying tax. Thus, the fifth hypothesis (H5) is:

H5: Taxpayers' satisfaction has a direct effect with tax compliance behavior

\section{CONCLUSION}

Tax revenue is the important factor to support national development and its economic strength, particularly in developing countries like Thailand. Despite, Thai government is ineffective to levied tax and distribute of tax revenue to locality. At the present, local revenue is not enough for support local development activities works. As of this point, Thai government should change the national strategy into a local oriented one. Property tax is a major source of Thai local government revenue in the local government budget. Thus, it is necessary of self-governing is more land local levied tax. Based on this point, stated tax regimes all around the world are constantly looking for ways to improving their tax revenue collections.

The major factors influence taxpayer compliance behavior are the tax law fairness, tax law complexity and tax administrative system (Hanefah, 1997). The efficiency and productivity of the tax administrative system in developed countries like USA and UK were determines the amount collected for any particular year of theSelf Assessment System (SAS). The governments of such countries have collected local tax in the form of a property tax with progressive rate (Palil, 2010). Therefore, they can collect more due to high tax rate.

There are four sources antecedent factors were identified in this study. They are tax fairness perception, tax knowledge and understanding, attitude towards taxation and service quality. These factors were assuming efficiency in tax collection which effecting to taxpayers' satisfaction and their compliance behavior. Structure Equation Modeling (SEM) will be tested the cause relationship among tax fairness perception, tax knowledge and understanding, attitude towards taxation and service quality with taxpayers' satisfaction and their compliance behavior empirically. Thus, focusing on these particular research factors will motivating local people willingness to pay tax and enhance the effective of government tax collection.

In summary, a shortage of government revenue and social infrastructure in Thailand urban area was caused by ineffective of local government levied tax. In fact SAO has not received sufficient revenue to expend for local demand. Despite, in Thai urban area emerging needs basic infrastructure, technology, education, and medical treatment for improving Thai people's quality of life. Thus, central and local government must be strengthened to be selfreliance by seeking revenue to meet the expenses and demand. Consequence, land local tax is the important source of local government revenue for development community. Therefore, this research will be focus on land local tax and identify the strategic factors for enhancing of local government revenue and improve living standard of Thai local people.

\section{CONTRIBUTION OF THE STUDY}

The revenue of local development was from property tax which includes hotels, apartments following by signboard tax and building and land tax. These kinds of tax are locally collected and calculated based on renting rate. Moreover, these kinds of tax are very

IBT Journal of Business Studies (Formerly Journal of Management \& Social Sciences) 
sensitive for taxpayer due to strict regulation, thus, they are voluntary to pay to avoid problem that may concerned to their business.

Despite, there are very limited researches on tax as major source of national revenue. From the past literature we found only research in tax-orientation. This past research was done on efficiency tax collection variables.

Thus, this study is the primary research identifying the components of tax fairness perception, tax knowledge and understanding, attitude towards taxation, service quality and their effects on taxpayers' satisfaction. The compliance behaviors of taxpayer in this study measure into two perspectives are as willingness and participation of taxpayer (refer to figure 1 Theoretical Conceptual Framework). By using the conceptual of this research via the effective methodology enable the academic and practitioner awareness the significance of taxpayer perception, satisfaction which motivating them to participate in local tax procedure. Hence, following this research structure and its practitioner outline will be contributing to the new knowledge of local taxpayer's satisfaction. What do they need and willing to participate in tax process provide by local government. Finally, the overall picture of this study will contribute to government revenue, national income and country development, respectively.

\section{REFERENCES}

Cannan, E. (ed). (1976) An Inquiry into the Nature and Causes of the Wealth of Nations: Adam Smith in 1723-1790. Chicago: University of Chicago Press, 1976. Available online at:

http://www.econlib.org/library/Smith/smWN.html.

Chanpaisansin, P., Meemak, V., and Chayachavalit, C. (2007). Performance Outcome of Bangkok Metropolitan Administration: A Comparative Study Between Classic Public Administration and New Public Management. Education Science Academic Journal ,8(3) September - December.

Cheutong, N. (2007). Problems and Obstacles of Tax Collection of HuaiKhaoKamTambon Municipality, Chun District, Phayao Province.

Conrad Adenau. (2005). Commission of Senate in The Foundation of ConradAdenoa held operating seminar about "National Period in Local Administrative". The Institute of Consultant for Official Development, on July 18, 2005 at The Institute of Chulaporn Research, Don Muang, Bangkok, which referred to the point of national period NO.5 in "Ability Developing on Income and Revenue Management for Local Administrative Organization".

Gilligan, G., and Richardson, G. (2005). Perceptions of tax fairness and tax compliance in Australia and Hong Kong - a preliminary study. Journal of Financial Crime 12(4):331343.

Hair, F., Black, C., Bahin, J., and Anderson, E. (2010). Multivariate Data Analysis: A Global Perspective", Pearson Prentice Hall, New York, NY

Hanefah, H. M. (1997). An Evaluation of the Malaysian Tax Administrative System, And Taxpayers' Perceptions Towards Assessment Systems, Tax Law Fairness, And Tax Law Complexity.

Hongvivatana, T. (1972). Local Government Finance in Thailand. June 1972. 
Julaphanthong, P. (2010). The Study of Exposure and Satisfaction towards Advertising Media of the Entrepreneur in Siam Square Area. An induvidual study submitted in partial fulfillment of the requirements for the degree of Master of Arts program in Mass Communication Administration. Thammasart University.

Keopradit, N. (2009). Tax Administration of Kaorubchang Municipality, Maung District, Songkhla Province.

Krueathep, W. (2012). Practices and Challenges of Participatory Budgeting in Thailand: A Case Study of Three Small Towns. Paper prepared for the International Conference on Political Science, Public Administration and Peace Studies, Prince of Songkla University, Hat Yai, Septembewr 6-7, 2012.

Lapiratanakul, V. (2006). Public Relations. Bangkok: Chulalongkorn University Press. Edition-11.

McBarnett, D. (2006 ). When compliance is not the solution but the problem: From changes in law to changes in attitude. Canberra: Center for Tax system Integrity, Australian National University,

Nantatikul, N. (2002). The Efficiency of Tax Collective Administration. Study on Satisfaction Dimension of people to Tax service system of Municipality : A case study in ThakamTambon Municipality, BangpakongAmpur, Chachoengsao.

Office of the Decentralization to Local Government Organization Committee (2009). Revenue Distribution to Local Administrative Organization during the Fiscal Year 2001 - 2008. Office of the Permanent Secretary the Prime Minister's Office. September 2008.

Palil, M. R. (2010). Tax knowledge and tax compliance determinants in self assessment system in Malaysia. PhD thesis, The University of Birmingham.

Phalalerd, N. (2005). A Survey of Listening Behavior to RuamDuaiChuaiGan Radio Program: The Department of Fisheries Radio Station, FM. 101.6 MHz, Roi Et Province. An independent study submitted in partial fulfillment of the requirements for the degree of Master of Communication Arts. SukhothaiThammatirat Open University. 2005.

Pongwichai, S. (2009). Research Design.In Teaching Document for graduate. Unit 2.Nontaburi: Sukhothaithammathirat.

Pornchokchai, S. (2009). Property taxes: What the public will benefit. Press Release No. 15/2552: PR Group. Fiscal Policy Office. July 24, 2009.

Prajuabmoa, S. (2001). Income Collection Measures of TAO. An interview in "OIB meet the public". the National Assembly Radio Station.

Prasith-rathsint, S. (2009). Multivariate Techniques for Social and Behavioral Sciences Research, (Handbook for Researchers and Graduate Students), Principles, Methods and Applications. Edited $6^{\text {th }}$. Bangkok: Samlada.

Promjui, S. (2001). "Population and Sampling” in Teaching documents: the Research Cooperative Methods. Unit 7.Sukhothaithammathirat University Printing.

Puang-ngam, K. (2009). Thailand Local Administration: Development and Reform. Bangkok, Faculty of Social Welfare Science. Thamasart University.

Puang-ngam, K. and Chotchuang, P. (2001). What? Why? How? SAO: Democracy of people in rural. Printed $12^{\text {th }}$. Bangkok: Dueantula. 
Ramangkoon, W. (2009). The conclusion of academic seminar of the Fiscal Policy Office NO.6, 2009. Finance Information Group. Office of Permanent Secretary, Ministry of Finance.Thai government. July 23, 2009.

Ruangpeung, P. (2002). People's Satisfaction to Public Goods and Service of JompolJaoprayaTambon Municipality, PluakdangAmpur, Rayong Province.

Seemanee, S. (2003). The Factors Related to the Clients' Satisfaction in Primary Care Unit, Saraburi Province. A Thesis submitted in Partial Fulfillment of the Requirements for the degree of Master of Science (Public Health). Mahidol University.

Siriwat, P. (2009). The Acceptance of Public Participation in the Administration of a Tamton Municipality.

Sonnakul, J. (1990). Local Revenue and Basic Democracy Developing. Bangkok.

Sookasame, K., and Prasith-rathsint, S. (2007). Handbook of LISREL Application. Bangkok: Samlada. January 2007.

STOU. (2009). THESIS. Codified matter subject for graduate of Management Science. Unit No. 1-5. Edited $8^{\text {th }}$.Nontaburi: SukhothaiThammathirat Open University Printing.

Suthirat, N. (2002). Performance Problem on Tax Base Policy. Bangkok.

Sweangdee, Y. (2011). Statistics and Social Science: Weakness and Strength in Context of Thai Academy. Keynote address in The $12^{\text {th }}$ National Conference on Statistics and Applied Statistics 2011 "Open Network for Gaia Research Using Appropriate Methodologies: ONGRUAM”. J.B. Hotel, Hat Yai, Songkhla. 18-22 May 2011.

Tayib, M. (1998). The Determinants of Assessment Tax Collection: The Malaysian Local Authority Experience. Thesis submitted in partial fulfillment of the Doctor in Philosophy. University of Glammorgan.

Thongboonma, K. (2010). Communication Satisfaction and Job Satisfaction of MahidolWittayanusorn School. An Individual Study Submitted in Partial Fulfillment of the Requirements for the Degree of Master of Art Program in Corporate Communication Management. Thammasat University.

Thoomkosit, U. (2009). Modern Local Government: The Lesson Learned from Development Country. Bangkok: Z4 Printing.

Thuwachot, S. (2001). Cooperative Research Methodology. Bangkok: Kasetsart University.

Trakarnsirinont, P. (2007). Governmental Fiscal. Bangkok: Sukhothaithammathirach University.

Vachirawanwong, P. (1988). Ability to provide revenue of Local Administration Authorities: a case study in municipality.

Wiersma, W. (1986). Research Methods in Education: An Introduction (4 ${ }^{\text {th }}$ ed.). Boston. Allyn and Bacon, Inc.

Wiratchai, N. (1995). LInear Structural RELationship (LISREL). $2^{\text {nd }}$ ed. Bangkok: Chulalongkorn University Printing.

Wiriyathampisan, K. (2002). The Application of Geographic Information System for Local Tax Collection Planning: A Case Study of Tambon Kham Thale So Municipality Amphoe Kham Thale So NakhonRatchasima Province. 
Wongkiatkhajorn, P. (2009). Strategic Concept in Developed Administrattion of Local Government Organization in Globalization. Bangkok: Panyachon. June 2009.

Yamane, T. (1967). Statistics: An Introductory Analysis. New York: Happer and Row.

Yarnmanowisit, T. (2008). Fiscal and Budget Administration. Bangkok: MachalongkunCSB.

Yolao, D., and Kasemnet, L. (2008). The Evaluation of the Principal Research Project: Research and Development of Thai Behavioral Systems, Third Phase (2004-2008). 